\title{
Making CSR Mandatory in India-A Flawed Approach
}

\author{
Shashank Sharma
}

\begin{abstract}
The government of India is proposing amendments in the Companies act, 1956 by bringing Companies Bill, 2011. Once passed, this bill will make the Corporate Social Responsibility (CSR) mandatory for the companies covered under the Section 135 of the draft bill. The paper tries to bring forward the drawbacks of making CSR mandatory by enumerating various flaws in the analogy. The reasoning behind the opposition of the author towards this concept covered under various heads of Duty of the State, Autonomy of the Shareholders, Let the Investor decide, Lack of proper working model \& Conflict with the Constitution provisions has been pointed out in detail in the paper.
\end{abstract}

Index Terms-Corporate social responsibility (CSR), companies bill 2011, section 135, the companies act 1956 .

\section{INTRODUCTION}

In India, the Companies Act, 1956, is the most important piece of legislation that empowers the Central Government to regulate the formation, financing, functioning and winding up of companies. The Act contains the mechanism regarding organizational, financial, managerial and all the relevant aspects of a company [1].

The new Companies Bill, which will replace a half-a-century old Act, is expected to be brought before Parliament for consideration and passage in the upcoming session. If passed, the Bill will protect the rights of minority shareholders, bring about responsible self-regulation with adequate disclosure and accountability, and lesser government control over internal corporate processes [2].

Among a large number of changes to the original Companies Act, 1956, plus a number of amendments to the Bill as proposed in December 2011, the new Bill proposes that companies worth $\$ 100$ million or above or meeting other similar standards, would need to provide explanation if they failed to allocate at least $2 \%$ of their annual net profits towards activities deemed by government to be acts of corporate social responsibility [3].

The provision making the corporate Social responsibility mandatory is contained in Section 135 of the proposed Companies bill, 2011 [4]. As per the provision

Every company having net worth of rupees five hundred crore or more, or turnover of rupees one thousand crore or more or a net profit of rupees five crore or more during any financial year shall constitute a Corporate Social Responsibility Committee of the Board consisting of three or

Manuscript received September 10, 2012; revised December 14, 2012.

Shashank Sharma is with the B.B.A. (Hons.), LL.B.(Business Law Hons.) degree at the National Law University, Jodhpur, India (e-mail: shashank.nlu@gmail.com). more directors, out of which at least one director shall be an independent director.

The Corporate Social Responsibility Committee shall formulate and recommend to the Board, a Corporate Social Responsibility Policy which shall indicate the activities to be undertaken by the company as specified in Schedule VII (b) recommend the amount of expenditure to be incurred on the activities referred to in clause (a); and

The Board of every company referred to in sub-section (1), shall make every endeavor to ensure that the company spends, in every financial year, at least two per cent of the average net profits of the company made during the three immediately preceding financial years, in pursuance of its Corporate Social Responsibility Policy.

If the company fails to spend such amount, the Board shall, in its report made under clause (o) of sub-section (3) of section 134, specify the reasons for not spending the amount.

\section{THE InHERENT Flaws OF THE MOdEL}

Now, coming to the flaws of the mandatory Corporate Social Responsibility model which will be discussed in detail in this section.

\section{Duty OF THE STATE}

Harvard economist Theodore Levitt put it succinctly, 'government's job is not business, and business's job is not government'. [5] The responsibility of the society is always of the state, it cannot be burdened on private entities, especially if the country itself is a welfare state. The Constitution of India through the Directive Principles of State Policy \& Preamble tries to establish a welfare state. The Directive Principles contained in Part IV of the Constitution of India are guidelines to the central and state governments of India, to be kept in mind while framing laws and policies, These guidelines are concerned with welfare of the citizen. Therefore welfare is a prerogative of the state as mandated by Constitution of India.

The argument is further strengthened by the fact that the country is already taxing the people for this purpose. The model of mandatory corporate social responsibility would have been a nice idea in Tax Haven, but if the country is already taxing people than the proposition of making corporate social responsibility seems unnecessary. If the government was so concerned regarding the welfare of its people than it could have increased the taxes on these private players for the expenditure in social developmental activities.

Another question is regarding the lack of knowledge and expertise of financial corporation with respect to societal 
development \& its needs, the state is at the best position to take decision on this point. It has been rightly pointed out by theorists that "social contracts" are vague and immeasurable, unlike profit, and that corporate executives simply have no talent or expertise in spending money to foster social goods [6]-[8].

\section{AutonOmy OF SHAREHOLDERS}

In his book Capitalism and Freedom, Milton Friedman states: "There is one and only one social responsibility of business - to use its resources and engage in activities designed to increase its profits so long as it stays within the rules of the game, which is to say, engages in open and free competition without deception or fraud.'[7]

Frank Easterbrook and Daniel Fishel in The Economic Structure of Corporate Law, opines that a corporation is nothing but a nexus of contracts [8]. These contracts, among other things, generally assume that the managers of the corporation will maximize profits for the company's shareholders. Given this reality, Fishel claims that corporations are "incapable of having social or moral obligations much in the same way that inanimate objects are incapable of having these obligations."'[9]-[11]

It is for the shareholder to take decision regarding the affairs of the company \& has been held by Michigan Supreme Court in the case of Dodge v. Ford Motor Company [10]-[15] that Henry Ford owed a duty to the shareholders of the Ford Motor Company to operate his business to profit his shareholders, rather than the community as a whole or employees.

This raises the question with respect to the autonomy of shareholder which would be affected adopting a mandatory CSR model as per which $2 \%$ of the wealth has to be invested in CSR activities. There can be no justification by the government for playing with the autonomy of the shareholder if we combine this argument with my previous $\&$ the next argument.

\section{LET THE INVESTOR DECIDE}

One of the basic principle of economics is that let the demand \& supply decide the price of the product. Similarly, in the stock market the investors decide the price of the share $\&$ the fate of the company. If any company is showing an irresponsible attitude towards the society, the investors in the long run will show the company true picture by rejecting such company in the stock market. The point is that investor itself plays the role of checks \& balances in the stock market.

Since the socially irresponsible companies are likely to be rejected by investors in the long run, the companies automatically respect such opinion \& act responsibly for surviving in the long run. Therefore bringing the mandatory CSR model may affect the balance of the market where automatic checks \& balances are already present to ensure efficient $\&$ responsible functioning of the companies.

\section{LACK OF PROPER WORKING MODEL}

The government has failed to show any specific purpose for adopting such model or any objective for which such expenditure is to be made. In wake of this the government has not shown any intent for reduction of the burden of taxes by applying this model or the treatment of saving if any on part of the government due to adoption of such model. There is inherent vagueness associated with model as no instructions are in place regarding the implementation of such model.

Also there are important questions like a tobacco company complying with this model would stand on same footing of social responsibility with the company developing eco friendly products for the society which remain unanswered by this new provision to be introduced.

\section{Conflict with Constitutional Provisions}

Article $19(1)(\mathrm{g})$ of the Constitution of India provides the fundamental right to practice any profession, or to carry on any occupation, trade or business. The present provision of mandatory CSR affects the right of the corporation to freely carry on its business operation. The counter argument of the government on this would be the Clause (6) of the same article of the Constitution which provides that reasonable restrictions can be imposed in the interest of the general public.

But the real question is whether these restrictions are reasonable at all; Can the burden of charity be imposed by the government on the corporations? The presence of a moral provision in a statute dealing with corporate affairs is highly questionable \& raises doubts on reasonability of this restriction.

\section{REFERENCES}

[1] Business Portal of India. [Online]. Available: http://business.gov.in/starting_business/companies_act.php

[2] The Economic Times. New Companies Bill should ensure $2 \%$ spend on CSR: Parliamentary panel. [Online]. Available: http://articles.economictimes.indiatimes.com/2012-08-13/news/33182 845_1_new-companies-bill-internal-corporate-processes-csr-activities

[3] Shailaja D Sharma. Corporate social responsibility: Should govt force $\cos$ to spend or should companies volunteer. [Online]. Available: http://articles.economictimes.indiatimes.com/2012-05-19/news/31778 030_1_social-responsibilities-companies-act-companies-bill

[4] The draft of the Companies Bill 2011. [Online]. Available: http://www.mca.gov.in/Ministry/pdf/The_Companies_Bill_2011.pdf

[5] T. Levitt, The Dangers of Social Responsibility, Harvard Business Review, vol. 36, no. 5, pp. 41-50, 1958.

[6] D. S. Christopher, Where the Law ends: The Social Control of Corporate Behavior, pp. 111-21, 1975.

[7] E. K. Janet, The Creative Capitalism Spectrum, TEMP. L. REV, pp. 869-870, 2008.

[8] R. S. Steven, True Codes Versus Voluntary Codes of Ethics in International Markets: Toward the Preservation of Colloquy in Emerging Global Communities, pp. 327-29, 1994.

[9] M. Friedman, The Social Responsibility of Business Is To Increase Its Profits, Sept. 13, 1970.

[10] H. Hansmann and R. Kraakman, The end of History for Corporate Law, 2001.

[11] J. R. Macey, An Economic Analysis of the Various Rationales for Making Shareholders the Exclusive Beneficiaries of Corporate Duties, vol. 23, 1991.

[12] F. Easterbrook and D. Fishel, The Economic Structure of Corporate Law, vol. 12, 1996. 
[13] A. A. Berle and C. Gardiner, The Modern Corporation and Private Property, 1932.

[14] D. Fishel, The Corporate Governance Movement, vol. 35, pp. 1259-1273, 1982.

[15] Mich 204 Mich. 459, 170 N.W. 668, 1919.

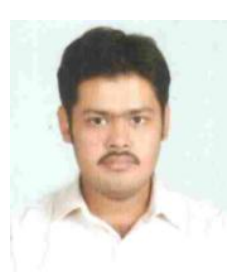

Shashank Sharma was born on August 26, 1991. He is currently living in his hometown Jodhpur situated in Rajasthan, India. He is pursuing a B.B.A (Hons.), LL.B. (Business Law Hons.) course from one of the premier institutions of the country National Law University, Jodhpur. He has earned a diversified work experience from internships with Oil \& Natural Gas Corporation Ltd., Defence Estates Department of Ministry of Defence of India, High Court lawyers, Law Firm \& NGO. Mr. Sharma has presented papers in three nationa conferences \& has also been a part of Model United Nations organized by IIT, Delhi. He is currently a member of the Center for Competition Law \& Policy in his Institution. 